\title{
NUZŪL OF THE QUR'ĀN AND THE QUESTION OF NUZŪL ORDER
}

\author{
Mustafa Öztürk \\ Çukurova University, Adana-Turkey
}

E-mail: ozturkm@cu.edu.tr

\begin{abstract}
In the modern Islamic world, there is growing interest in reading and interpretation of the Qur'ān according to its nuzūl order; accordingly, many translations and exegeses, based on nuzūl order, are published every day. This fact compels us to consider questions about the descent of revelation, arrangement of the text of the Qur'ān, and its arrangement pursuant to the chronology of revelation, as well as relevant general acceptance. Classical references seldom questioned the reliability of revelation order narrated by Șạāba (Companions), such as 'Alī ibn Abī Ṭālib and 'Abd Allāh ibn 'Abbās, and Tābi'ūn (Followers), such as Jābir ibn Zayd, al-Hasan al-Bașrī, and Ibn Shihāb al-Zuhrī, as well as later personalities, such as Jaffar al-Ṣādiq, alWāqidī, and other scholars; moreover, it has never been extensively studied whether all of the sūras (chapters) of the Qur’ān can be chronologically arranged pursuant to the available information. Herein, this study intends to draw attention to the necessity for a serious examination and analysis of such issues regarding the revelation and arrangement of the Qur'ān.
\end{abstract}

Key Words: Nuzūl, tartībal-Qur’ān, nuzūl order, inzāl, revelation. 


\section{Introduction}

The revelation of the Qur'ān to Muhammad is expressed in many âyas (verses) through mașdar (verbal noun) such as nuzūl, inzāl, and tanzīl or verbs derived from these nouns. The word nuzūl is mentioned in approximately three hundred verses and is attributed to divine revelations, such as the Torah, Bible, and the Qur'ān, in verses and chapters, as well as to tangible or intangible things such as angels, devils, provisions, water, clothes, meals, benevolence, torment, measures, sultans (strong evidence), peace, and calmness. In Arabic, nuzūl means "to descend, to lodge." According to some linguists, its essential meaning is "to descend," while others believe that nuzūl actually signifies $b u l \bar{u} l$, in other words, "to arrive and settle in somewhere."

According to certain scholars, such as al-Rāghib al-Ișfahānī (d. $1^{\text {st }}$ quarter of $5^{\text {th }} / 11^{\text {th }}$ century), the utilization of $n u z \bar{u} l$ on the pattern of if $\bar{a} l$ (i.e., inz $\bar{a} l$ ) with reference to the Torah and Bible, and on the pattern of $\operatorname{taf}(\bar{l} l$ (i.e., tanzīl) with reference to the Qur'ān's revelation, signifies a semantic nuance. Therefore, the verbal noun inzāl signifies "descending" both "at once" and "gradually," while tanzīl exclusively means "gradual" and "sending down." ${ }^{2}$ Nevertheless, some other scholars have claimed that there is no semantic difference between inzāl and tanzīl, which, according to us also, are synonymous. Indeed, al-Suyūți (d. 911/1505) related the common acceptance among scholars that the Torah and Bible descended at once but added that contemporaneous scholars rejected such an argument due to a lack of appropriate evidence and justification. ${ }^{3}$

For Quṭb al-Dīn al-Rāzī (d. 766/1365), because Allah is non-spatial, and the Qurān has a nature of meaning that can replace the divine

1 Abū l-Ḥusayn Aḥmad ibn Fāris ibn Zakariyyā', Mu'jam maqāyīs al-lugha (ed. 'Abd al-Salām Muhammad Hārūn; $3^{\text {rd }}$ edn., Cairo: Mușțafā al-Bābī al-Halabī, 1979), V, 417; Abū l-Fạ̣l Muhammad ibn Mukarram Ibn Manẓūr, Lisān al-'Arab (Cairo: Dār al-Hadīth, 2003), VIII, 523.

2 Abū l-Qāsim al-Ḥusayn ibn Muhammad al-Rāghib al-Iṣfahānī, al-Mufradāt fì gharīb al-Qur'ān (ed. Muhammad Khalaf Allāh; Cairo: Maktabat al-'Anjlū alMișriyya, 1970), 744.

3 Abū l-Fạ̣l Jalāl al-Dīn 'Abd al-Raḥmān al-Suyūțī, al-Itqān fì 'ulūm al-Qur'ān (ed. Mușțafā Dīb al-Bughā; Beirut: Dār Ibn Kathīr, 2002), I, 134. 
personality, it is not permissible to ascribe the meaning "to make to descend from above" to the verbal nouns of inzāl-tanzìl about revelation of the Qur'ān to the Prophet. The lexical meaning of inzāal is "to accommodate, to host" ( $\bar{\imath} w \bar{a}$ ') and "to move something downward;" nonetheless, neither meaning seems accurate when the usage is related to discourse/word. Thus, the noun inzāl is only figuratively applied for abstract concepts, such as discourse/word. ${ }^{4}$

Such an explanation might work in the context of discourse or belief related to discussions of divine attributes; however, it does not seem accurate with regard to the historical and social context in which the Qur'ān was revealed. Accordingly, some verses read that Allah is in the sky. For example, Q 67:16 indicates that Allah is in the sky, while Q 6:158 and Q 2:210 discuss the advent of Allah or His appearing among the clouds. Q 2:144 indicates how Muhammad turns his face toward the sky; according to exegetes, this action signifies his waiting for a revelation of the change of Qibla and the consideration that Gabriel sent the revelation from the heavens. ${ }^{5}$ In addition, Q 51:22 reads, "And in the heaven is your provision and whatever you are promised." In a well-known hadith, a concubine is asked, "Where is Allah?," whereupon she responds, "He is in the heavens," and then Muhammad says, "Set her free, for she is a believer."

In his interpretation of the expression man $f \bar{l} l$-sama $\bar{a}$ in Q 67:16, the Mu'tazilī exegete Abū Muslim al-Iṣfahānī (d. 322/934) writes the following: "Arabs accepted the existence of Allah, but also believed that He was in heaven. This is why, Allah says, 'Do you feel secure that He who holds authority in the heaven would not cause the earth to swallow you, and suddenly it would sway?"7 In contrast, according

Ibid., 138.

5 See Abū 'Abd Allāh Muḥammad ibn 'Abd Allāh ibn 'Īsā Ibn Abī Zamanīn, Tafsìr al-Qur'ān al-'azìz (Beirut: Dār al-Kutub al-'Ilmiyya, 2002), I, 185; Abū Hafș 'Umar ibn 'Alī Ibn 'Ādil, al-Lubāb fì 'ulūm al-Kitāb (eds. 'Ādil Aḥmad 'Abd alMawjūd and 'Alī Muḥammad Mu'awwaḍ; Beirut: Dār al-Kutub al-'Ilmiyya, 1998), III, 31-32.

6 See Abū Sa'īd 'Uthmān ibn Sa'īd al-Dārimī, al-Radd 'alā l-Jahmiyya (ed. Badr alBadr; Kuwait: al-Dār al-Salafiyya, 1985), 38-39.

Abū 'Abd Allāh Fakhr al-Dīn Muhammad ibn 'Umar al-Rāzī, al-Tafsīr al-kabīr aw Mafātīḥ al-ghayb (eds. Ibrāhīm Shams al-Dīn and Aḥmad Shams al-Dīn; $2^{\text {nd }}$ edn. 
to several hadith narratives, Allah descends to the earthly skies every night, and in the small hours, He says, "Isn't there anyone praying to Me; I would respond such prayers ...;" some other narratives relate that Allah will descend to Earth on judgment day to hold people accountable. ${ }^{9}$

\section{Mode of Descent of the Qur'ān's Revelation}

Many verses and hadiths indicates that the revelation of the Qur'ān occurred by descent from heaven to earth. Nevertheless, this explanation is closely related to traditional beliefs and conceptions of first addressees and/or Arabs in Muhammad's time with regard to abstract beings in general and Allah in particular. More precisely, the imagination of pre-Islamic Arab society conceived Allah and angels as heavenly beings; therefore, the Qur'ān indicates that revelation was sent from heaven down to earth.

Indeed, as indicated in Q 15:17-18, Q 26:210-212, Q 37:7-10 and Q 72:8-9 about istirāq al-sam ' (attempt by a jinn to steal news from heaven), for Arabs in the time of revelation, it was impossible for a human to be in direct contact with Allah or the space of abstract beings, and such a connection could only be established by virtue of the jinn (demons and angels); pursuant to this conventional belief, such intermediary beings are expressed via words or concepts such

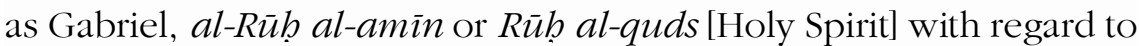
descent of the Qur'ān's revelation.

In addition, Q 36:69-70, Q 52:29, and Q 69:41-43 negate the conventional beliefs and arguments of polytheists about istirāa al-

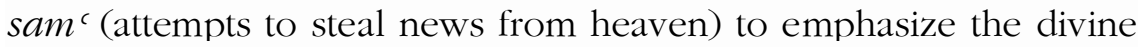
nature of the Qur'ān's revelation; moreover, these verses indicate that Muhammad was not one among seers or poets who were believed to have contact with the jinn and to obtain information from them, that the Qur'ān was sent by Allah, the God of the universe, and that it is not the word of seers or poets.

Then again, Q 15:9 and Q 56:77-79 read that the Qur'ān was sent from the presence of Allah and was protected from intervention by

Beirut: Dār al-Kutub al-'Ilmiyya, 2004), XXX, 61-62.

Al-Bukhārī, "Tahajjud," 14; Muslim, "Ṣalāt al-musāfirīn," 168-172.

9 Al-Tirmidhī, "Ṣawm," 39; "Zuhd," 48. 
evil beings such as jinn and demons, and only mutahhar (those purified/made purified from evil and sin) beings can have contact with it. The word mutahbarūn in Q 56:79 has been interpreted as "angels" by exegetes such as Ibn 'Abbās, 'Ikrima, Mujāhid, and Sa'īd ibn Jubayr. ${ }^{10}$

In pre-Islamic Arab tradition, abstract/spiritual beings were classified as good and evil or pious and malignant; angels are accepted as good and pious, whereas demons are considered evil and malignant. In addition, during Days of Ignorance, the jinn were categorized as follows: those that lived together with humans were called "āmir," those that interfere with and hurt children were called "arwāḥ," those with evil and stubborn natures were called "shayțān," those that were extremely evil were called "mārid," and those that committed violence for evil were called "ifrit;" in contrasts, the jinn, which are pure and clean and far from evil, were qualified as "angels." 11

Because the descent and sending of revelation, as well as guidance and administration, are believed to have been performed by means of angels since the former Semitic-Hebrew culture, pre-Islamic Arabs most probably owed this point of view to Ahl al-kitāb in general and to Jews in particular. In Jewish tradition, various words/concepts, such as theophany, visions, and dreams, are employed to express revelation as direct conversation of God with humans; nevertheless, the concept of angels, which are referred to as "angels of Jehovah" or "angels of the Lord" in the Tanakh, possess peculiar importance.

These angels are sent to establish communication with humans as abstract beings that act for God and speak on His behalf. Many expressions in the Tanakh identify the angel of God with God Himself due to its connection with the divine source. The identification that was established between the angel and God caused

\footnotetext{
10 See Abū l-Faraj Jamāl al-Dīn 'Abd al-Raḥmān ibn 'Alī Ibn al-Jawzī, Zāed al-masīr fì 'ilm al-tafsīr ( $4^{\text {th }}$ edn., Beirut: al-Maktab al-Islāmī, 1987), VIII, 152.

11 For further information see Jawād 'Alī, al-Mufașṣal fì tārīkh al-'Arab qabla $l$ Islām (Qom: Manshūrāt al-Sharīf al-Raḍī, 1380), VI, 705-725.
} 
people to fear these angels so much that it was considered as dangerous to see the angel of God as to see God in person. ${ }^{12}$

In this regard, the dialogue in the Qur'ān between Mary and the angels ${ }^{13}$ and the fear of Mary of the angel, which, in the guise of a human, heralds to her the good news of a child, ${ }^{14}$ seems to reflect the perception of angels in Jewish tradition. Indeed, statements in the Qur'ān about many issues, including creation and sharī'a, fables and revelation, coincide with their counterparts in the Torah and Tanakh. The emphasis in various verses on how the Qur'ān confirms the Torah ${ }^{15}$ might be considered related to this question. Conversely, the first Muslims reportedly used to meet and exchange ideas with Jews in Medina; even some famous Companions went to Bayt al-midrās in Medina to participate in Torah discussions with Jewish men of the cloth and had occasional debates with them. ${ }^{16}$

Because Allah was believed to be from heaven within the earliest circle of addressees, it is normal that, in some Qur'ān verses, things such as iron, clothes, and cattle are said to be sent from heaven to earth, just like revelation. Nevertheless, such verbiage is not intended to inform ( $f \bar{a}^{\prime}$ idat al-khabar) the primary and directly addressed masses but to provide them with another message (lāzim al-fáa'ida) by means of what is known to them.

In other words, the Qur'ān does not bring forth definitive/descriptive and primary statements about actual facts with regard to the presence of Allah in heaven and descent of many other things from above; rather, the text interprets and formats these words to reflect the imagination of Arab society. As a matter of fact, pursuant to the expression anzalna $\mathrm{l}$-ḩadid in Q 57:25, which literally means "we sent down iron," there is a narrative ascribed to the companion Ibn 'Umar. According to the narrative, Allah sent down four things from heaven to earth as benedictions: iron, fire, water, and salt.

12 For further information see Muhammet Tarakç1, "Tanah'ta Vahiy Anlayış1," Uludağ Üniversitesi İlabiyat Fakültesi Dergisi 11/1 (2002), 193-218.

13 Q 3:42-51.

14 Q 19:17-18.

15 Q 3:50; 5:46; 61:6.

16 See Abū Ja'far Muhammad ibn Jarīr al-Ṭabarī, Tafsìr al-Ṭabarī al-musammā Jāmī al-bayān fì ta'wīl al-Qur’ān (3 ${ }^{\text {rd }}$ edn., Beirut: Dār al-Kutub al-'Tlmiyya, 1999), I, 478; III, 217-218. 
Another narrative from Ibn 'Abbās claims that Adam came down to earth with a few objects made of iron, such as an anvil, a hammer, and needles/nails. ${ }^{17}$

Consequently, expressions in the Qur'ān about the form of descent of revelation have a conditional, contextual, and historical content. This fact is also evident in the example that, through the meaning "descent/sending down" of the word nuzūl/inzāl, together with the adjective of quality Qur'a $n^{a n}$ 'Arabiyy ${ }^{a n}$ (Q 12:2), divine revelation is formulated in harmony with Arab culture and mentality. However, in the history of Islamic thought, Mu'tazilī and Sunnī paradigms have claimed that Allah is independent of time and space with regard to discussions on divine attributes; thereupon, the expression man fi $l$-sama $\bar{a}^{\prime}$ (Allah, who is in heaven) in the related verse is construed to be a figurative metaphor for supremacy and sovereignty pursuant to this absolving approach. ${ }^{18}$ Similarly, the hadith on Allah's nightly descent to earth is considered to denote the descent of divine benediction and graces. ${ }^{19}$ Nonetheless, during the $2^{\text {nd }}$ and $3^{\text {rd }}$ centuries AH, Ahl al-hadīth and Salafī (Abl al-sunna al$k h \bar{a} s \underline{a} a)$ scholars claimed that the omnipresence of Allah, not in heaven but everywhere, was an argument and belief peculiar to Jahmiyya and Zanādiqa (heretics). ${ }^{20}$ Therefore, even faith in Allah, which is the strongest and solidest principle of Islamic faith, has interestingly undergone radical changes regarding perception and conception within a few centuries.

Regarding the word inzāl in the verses about the sending by Allah of iron, clothes, and cattle from heaven, it is explained as "to create or to bring forth means for a benefaction so that mankind benefits from

17 Abū 'Abd Allāh Muḥammad ibn Aḥmad al-Qurțubī, al-Jāmī' li-ạ̣kām al-Qur'ān (Beirut: Dār al-Kutub al-'Ilmiyya, 1988), XVII, 169.

18 Abū Hayyān Muḥammad ibn 'Alī ibn Yūsuf al-Andalusī, al-Bạ̣r al-muḥị fî̀ $l$ tafsìr (ed. Șidqī Muḥammad Jamīl; Beirut: Dār al-Fikr, 2005), VIII, 296.

19 Abū l-Sacādāt Majd al-Dīn Mubārak ibn Muhammad Ibn al-Athīr al-Jazarī, alNihāya fì gharīb al-hadìth wa-l-athar (ed. 'Abd al-Hamīd Hindāwī, Sidon \& Beirut: al-Maktaba al-'Așriyya li-1-Tawzī' wa-1-Nashr, 2008), V, 35.

20 See al-Dārimī, Naqd 'Uthmān ibn Sa'̄̀d 'alā l-Marīsì al-Jahmī al-'anìd fì-mā iftarā 'alà llāh fì l-tawḥ̄d (ed. Manșūr ibn 'Abd al-'Azīz al-Simārī; Riyadh: Aḍ̂ā' al-Salaf, 1999), 57-59, 62, 274-280. 
it." ${ }^{21}$ In the Qur'ān, inzāl is employed for revelation, as well as for concrete objects, such as clothes, iron, and cattle; it seems figuratively justifiable to ascribe to it the meaning "to create and introduce to the utilization of man;" nevertheless, we must remark that the original and historical signification in verses about the descent of revelation is "to send down from heaven."

At this stage, ascription of place to Allah might seem problematic in terms of faith. Nevertheless, this relationship did not constitute a problem for Muhammad and the generation of Companions; rather, it is disturbing for transcendentalist (tanzīh $\bar{\imath}$ ) kalāmī/theological paradigms with regard to divine attributes in the history of Islamic thought and for those who reject anthropomorphism (tashbih) and corporealism (tajsim). During lifetime of the Prophet, the primary concern among Muslims was not the problem of ascribing place to Allah; rather, the concern was to prevent any dispute regarding His unity (tawhid) and to negate any kind of polytheism. Therefore, such philosophical and discourse-related problems emerged in the course of a historical process; it would be anachronism to claim that such questions were an issue for the Prophet and his Companions.

\section{Stages of Descent of Revelation}

As is known, according to first verse in Sūrat al-Qadr, the Qur'ān was sent down on Laylat al-qadr (Night of Power); however, the content and mode of descent are not explained. Due to this vagueness, Islamic tradition has encompassed numerous viewpoints and convictions about how the Qur’ān was revealed. According to common opinion, the Qur'ān was sent down to the sky of the world as a whole on the Night of Power; then, it was gradually revealed to Muhammad in a series of incidents over the subsequent twenty years.

A second view, related by Muqātil ibn Hayyān (d. 150/767), argued that the Qur'ān was sent down to the sky of the world in annual revelations over twenty or twenty-three successive Nights of Power, before the gradual descent of these annual revelations during

21 Fakhr al-Dīn al-Rāzī, al-Tafsīr al-kabìr, XIV, 42; XXVI, 213; al-Qurțubī, al-Jāmīc, VII, 118; XV, 153; Abū Ḥayyān al-Andalusī, al-Baḥr al-muḥ̄ṭt, IV, 282-283; Ibn 'Ādil, al-Lubāb, XI, 66; XVI, 474-475; Muḥammad al-Ṭāhir ibn Muhammad ibn Muhạmmad Ibn 'Āshūr, Tafsīr al-taḥ̂rì wa-l-tanwīr (Tunis: Dār Saḥnūn, 1997), VIII, 73-74; XXIII, 332. 
the corresponding year. According to a third approach, narrated by Abū 'Amr al-Sha'bī (d. 104/722), the descent of the Qur'ān from alLawh al-mabfüz (Preserved Tablet) down to the sky of the world began on the Night of Power; later, it was gradually revealed in agreement with emerging incidents at various times. The fourth view defended the viewpoint that the Qur'ān was sent down from the Preserved Tablet as a whole; the hafaza angels gradually handed the text to Gabriel on twenty Nights of Power, whereupon Gabriel extended the process over twenty-something years and recited the Qur’ān to Muhammad. ${ }^{22}$

In all narratives about the aforementioned views and convictions, it is unclear what "sky of the world," or Bayt al-izza (House of Honor), signifies. In other words, the open question of the Qur'ān's revelation, after descent from the Preserved Tablet and before reaching the Prophet, remains unanswered. Some references claim that Ibn 'Abbās was the creator of the idea regarding the descent to Bayt al-'izza. Pursuant to the narrative, Ibn 'Abbās said, "The Qur'ān was taken from the seat of $d h i k r$ and placed at Bayt al-izza in the sky of the world. Gabriel gradually brought the Qur’ān from Bayt al"izza to the Prophet and slowly read it;" ${ }^{23}$ however, this narrative or any other report or work provides almost no information about the content of Bayt al-'izza.

Such vagueness and ambiguity might provide grounds for an assumption: Bayt al-izza was generated as a formula to explain the possibility of access to the Qur'ān's revelation, which is considered eternal in Sunnī tradition, in historical and human contexts. In earlier sources, however, the question "What is the secret behind collective descent of the Qurān to the firmament?" was answered with a romantic approach, namely "This is in order to glorify both the Qur'ān and Muhammad by means of declaring the Qur'ān as the final divine book (revelation) sent down to the inhabitants of the seven heavens and to the last prophet, Muhammad, the prophet of the most

22 Jamāl al-Dīn Abū 'Abd Allāh Muḥammad ibn Aḥmad ibn Sa'īd Ibn 'Aqīla, alZiyāda wa-l-ị̣sān fì 'ulūm al-Qur'ān (al-Shāriqa: Jāmi'at al-Shāriqa Markaz alBuhūth wa-l-Dirāsāt, 2006), I, 152-153.

23 Abū Bakr 'Abd Allāh Muhammad ibn Ibrāhīm Ibn Abī Shayba al-'Absī, Kitāb almușannaf fì l-aḥādìth wa l-āthār (ed. Mușțafā Kamāl Hūt; Beirut: Maktabat alZamān, 1999), VI, 144. 
valuable community." ${ }^{24}$ In fact, as the phrase "The Qur'ān was placed at Bayt al-izza so as to ensure its access to worldly (historical) context" ${ }^{25}$ by al-Hakīm al-Tirmidhī (d. 320/932) suggests, the generation of the concept of Bayt al-izza was probably devised for its entrance into historical context despite its eternal character; this approach might also have been adopted to prevent strengthening the hand of Mu'tazila with regard to khalq al-Qur'ān.

Indeed, all views about the descent of the Qur'ān consist of personal convictions, including that narrated via Ibn 'Abbās. At this point, one might object that Ibn 'Abbās cannot provide personal opinions about the status of the Qur'ān prior to its being encountered by man, history and society and that he must have obtained such information about Bayt al-'izza only from the Prophet; nevertheless, countless narratives in exegeses and hadith sources have indicated how the Companions suggested their opinions and personal convictions regarding issues about the unseen. More precisely, as various views of Companions about the issues regarding unseen, such as divine attributes, judgment day, the afterlife conditions, and creation, indicate, notable personalities provided their opinions since the earliest days of Islam.

In brief, considering both the general significance of verses about inzāl/tanzīl of the Qur'ān's revelation and the consequence of twenty-three years of revelation, the argument by al-Sha'bī, namely "Descent of the Qur'ān from the Preserved Tablet to the firmament began on the Night of Power, before it was gradually sent down pursuant to emerging incidents," seems more reasonable. Conversely, the ambiguities and disputes about what occurred during the transition of revelation from the seat of Allah to the Prophet seem ineradicable. Similarly, it remains controversial whether the Qur’ān descended to the Prophet only in meaning or both in meaning and words.

24 Abū 1-Qāsim Shihāb al-Dīn 'Abd al-Raḥmān Abū Shāma al-Maqdisī, al-Murshid al-wajīz ilā 'ulūm tata'allaqu bi-l-Kitāb al-‘azīz (ed. Tayyar Altıkulaç; Ankara: Türkiye Diyanet Vakfı Yayınları, 1986), 24; Abū 'Abd Allāh Badr al-Dīn Muḥammad al-Zarkashī, al-Burhān fì 'ulūm al-Qur'ān (ed. Muḥammad Abū 1Faḍl Ibrāhīm; Sidon \& Beirut: al-Maktaba al-'Așriyya, 1972), I, 230.

25 Al-Suyūṭī, al-Itqān, I, 132; Ibn 'Aqīla, al-Ziyāda wa-l-iḅsān, I, 156. 
Pursuant to the dominant conception and conviction, the revelation of the Qurān belongs to Allah in terms of both wording and meaning. Gabriel memorized the Qur'ān's revelation from the Preserved Tablet and thus sent it down to the Prophet. According to another, allegedly marginal approach, Gabriel provided the Qur'ān only in meaning, and later, the Prophet formulated the text in Arabic words. A third view defends the idea that Qur’ān was communicated to and inspired in Gabriel in meaning, whereupon the angel translated it into Arabic words and gave it to the Prophet. ${ }^{26}$

Al-Imām al-Māturīdī (d. 333/944) ascribed the second argument to Bāținī circles, which most probably included certain philosophers as well. Al-Māturīdī cited the Bāṭinī view precisely: "The Qurān was sent down to the Prophet not in the form of text, but as a type of inspiration to his heart; then, the Prophet expressed it with Arabic wording for concretization," pursuant to Q 2:97; al-Māturīdī criticized this argument because the Qur’ān provides very strong evidence of its miraculous character. In addition, Bāținiyya adopts the approach that "The Qur'ān was sent down to the Prophet in a form without any linguistic character - just like a dream; the Prophet put it in Arabic form through his language" with reference to Q 26:192-195; however, grounded on Q 12:2 - "Indeed, We have sent it down as an Arabic Qur'ān that you might understand' - al-Māturīdī rejected the foregoing Bāṭinī assumption. ${ }^{27}$

Ahl al-sunna traditionally refused the claim that revelation was sent to the Prophet in the form of pure meaning and called such allegations heresy. The Sunnī view thus intends to refute the Mu'tazili view of createdness of the Qur'ān and to develop a theory of the miraculous nature of the Qur’ān by describing it as a linguistic miracle in literary terms. The purpose of the latter assumption is to describe the Qur'ān in terms of both meaning and wording and to generate a jurisprudent and faith-related doctrine that Arabic should necessarily be the language of worship in Islam. Nevertheless, our opinion about the content and form of the descent of revelation is

\footnotetext{
26 Al-Zarkashī, al-Burhān, I, 229-230; al-Suyūṭī, al-Itqān, I, 139.

27 Abū Manșūr Muhammad ibn Muhammad ibn Maḥmūd al-Māturīdī, Ta’wīlāt Abl al-sunna: Tafsìr al-Māturīdì (ed. Majdī Bāsallūm; Beirut: Dār al-Kutub al-'Tlmiyya, 2005), I, 517-518; VIII, 85.
} 
closer to that of the philosophers who are categorized as "Bāținiyya" by al-Māturīīi, rather than the dominant approach. ${ }^{28}$

The ambiguity and gaps regarding the content and form of the descent of the revelation are also present with regard to issues such as which chapters were revealed in Mecca or Medina, as well as the inner organization and composition of the text of the Qur'ān. Over the twenty years of the revelation process, verses revealed in first decade are called Makkī (from Mecca), while those in the following thirteen years are known as Madanī (from Medina). Nevertheless, there are many disputes regarding how to determine Makkī and Madanī chapters. According to a narrative of Ubayy ibn Ka'b, 27 chapters are Madanī, whereas 87 are Makkī. According to Abū l-Fath Ibn Shịțā (d. 450/1059), 29 chapters are Madanī, while 85 are Makkīī; nevertheless, it is arguable whether the chapters al-Qamar, alRaḥmān, al-Ikhlāṣ, al-Falaq and al-Nās are Makkī or not. According to Abū l-Ḥasan ibn al-Hașșār (d. 611/1215), 82 chapters are undoubtedly Makkī, and 20 are undoubtedly Madanī, whereas the remaining 12 are disputable. ${ }^{30}$

Such disputes arose due to a lack of interest of the Prophet and Companions in technical issues such as the Makkī or Madanī character of the chapters; accordingly, they arose from a lack of explicit information from him and his Companions. As al-Bāqillānī (d. 403/1013) clearly asserted, the Prophet never said a word about the issue of Makkī-Madanī; moreover, there are no narratives indicating that he ever classified Qur'ān chapters in this regard or told his Companions "Mind that these chapters were sent down to me in Mecca, and those were sent to me in Medina." 31 This lack of direction exists because the Prophet and the Companions conceived the Qur'ān's revelation not as a text to be recorded in terms of time and

28 Our views and opinions about the content of revelation will be extensively treated in our books about the history of the textualization of the Qur'ān and relevant problems of historicalness/historicity.

29 Ibn al-Jawzī, Funūn al-afnān fì 'uyūn 'ulūm al-Qur'ān (ed. Șalāḥ ibn Fatḥī Halal; Beirut: Mu’assasat al-Kutub al-Thaqāfiyya, 2001), 160.

30 Al-Suyūṭī, al-Itqān, I, 33; Ibn 'Aqīla, al-Ziyāda wa-l-ị̣sān, I, 206.

31 Abū Bakr Muhammad ibn al-Ṭayyib al-Bāqillānī, al-Intiṣār li-l-Quròān (ed. Muḥammad 'Isām Muflị̣ al-Quḍāt; Amman \& Beirut: Dār al-Fatḥ li-l-Nashr wa-1Tawzī‘ \& Dār Ibn Hazm, 2001), I, 247. 
place of descent but as a divine guide within their life experiences and struggles against opponents of the invitation to Islam; consequently, the statements/orders in this guide were understood spontaneously and implemented in life practice as natural attitudes and behaviors.

\section{Arrangement of the Qur'ān Text and the Question of Presentation ( 'Arda)}

As is known, the arrangement of chapters within the Qur'ān text from cover to cover is now called the "Muṣhaf arrangement;" in general, the arrangement is attributed to the commission of copiers established under leadership of 'Uthmān. Suitably, it is widely accepted that the arrangement of verses within chapters was undertaken at the discretion of the Prophet and that he established the arrangement at the behest of Gabriel, ${ }^{32}$ pursuant to several narratives. Therefore, the arrangement of the verses is made according to divine ordinance (tawqifi). The narratives about presentation ('arda), which indicates mutual recitations by Muhammad and Gabriel during Ramaḍān of verses and chapters sent down in the relevant year, ${ }^{33}$ are used as proof of this general acceptance.

Nevertheless, these narratives, regardless of questions about their authenticity, provide no significant information about the content of carda (mutual lecture and presentation); instead, they discuss presentation as a very mysterious phenomenon. It is likely that the narratives about presentation were fabricated to fill the gaps with regard to the textualization process of the Qur'ann. Indeed, these narratives include no explanatory information about when the presentation began, how many times it actually occurred over the twenty-three years of descent, who read the Qur'ann during the presentation, how and in which appearance Gabriel participated in the presentation, whether the Companions were present at these sessions or whether Companions such as Ibn Mas'ūd and Zayd ibn

\footnotetext{
32 Aḥmad ibn Hanbal, al-Musnad, I, 57; IV, 218.

33 See al-Bukhārī, "Bad' al-waḥy," 5; "Faḍā’il al-Qur’ān," 7; "Bad' al-khalq," 6; Muslim, "Faḍ̄àil al-ṣaḥāba," 98-99.
} 
Thābit, who - according to some narratives - participated in the presentation, saw Gabriel in person. ${ }^{34}$

Grounded on Companions such as ' $\overline{\mathrm{A}}$ 'isha and Ibn 'Abbās, hadīth sources relate that the presentation occurred once yearly during Ramaḍān and twice in the final Ramaḍān of Muhammad; according to the narrative via Abū Hurayra, the Prophet used to confine himself in a mosque (ictikâf) for ten days every year, but he stayed in the mosque for twenty days in the year of his death. ${ }^{35}$

Muhammad Hamīd Allāh claimed that the practice of presentation might have begun after the assignment of Ramadān as the month of fasting during the Medina period; ${ }^{36}$ some researchers, however, have interestingly argued that "the mentioned month was already called Ramaḍann before fasting became an obligation. The month was not called Ramaḍān because of fasting; on the contrary, the fast was rendered an obligation in this month because the latter was already considered sacred." ${ }^{37}$

Prior to Islam, the four months, namely, Dhū l-qa'da, Dhū 1-hiija, Muharram, and Rajab, were known as "forbidden ( harām) months" and were considered holy; however, we have no historical data regarding whether Ramaḍann had such a status. Indeed, the importance of Ramaḍān emerged upon the revelation of Q 2:183 and subsequent verses, which designated fasting as a religious obligation. Fasting was made an obligation (fard) in $2 \mathrm{AH}$.

In his Lațā'if al-ma'ärif, Ibn Rajab (d. 795/1393) treated the obligatory or preferable worships and remembrances (adhkār [pl. of dhikr]) for each month as those of Muharram; about Ramaḍān, his writings consisted significantly of rituals such as fasting, Qur’ān

34 For comprehensive information and assessment, see Ziya Şen, "Arza ve Mahiyeti," Dokuz Eylül Üniversitesi İlahiyat Fakültesi Dergisi 42 (2015), 43-64.

35 Al-Bukhārī, "Faḍāil al-Qurān," 7; Abū l-Faḍl Shihāb al-Dīn Ahmad ibn 'Alī Ibn Hajar al-'Asqalānī, Fatḥ al-bārī sharḥ Șaḥ̄ḥ al-Bukhārī (eds. 'Abd al-'Azīz ibn 'Abd Allāh Ibn Bāz, 'Alī ibn 'Abd al-'Azīz al-Shibk, and Muḥammad Fu’ād 'Abd al-Bāqī; Riyadh: Dār al-Salām, 2000), IX, 54-55.

36 Muḥammad Hamīd Allāh [as Muhammed Hamidullah], İslâm Peygamberi (translated into Turkish by Salih Tuğ; Ankara: İmaj İç ve Dış Ticaret, 2003), II, 700.

37 Ziya Şen, Kur'an'm Metinleşme Süreci (Istanbul: Ensar Neşriyat, 2007), 120; Muhsin Demirci, Kur'ân Tarihi (Istanbul: Ensar Neşriyat, 2005), 114-115. 
chanting, confinement, and worshipping on Night of Power. ${ }^{38}$ In contrast to Ramaḍān, the months of Muharram and Rajab were considered important and holy as in the Days of Ignorance. Indeed, the history of traditions, such as the fast of 'Āshūrā' and the sacrifice of Rajab, dates from the pre-Islamic era.

In the Days of Ignorance, Ramaḍān was classified among the usual or ordinary months, including Sha'bān and Shawwāl. Conversely, Arabs in the Days of Ignorance had the tradition of tabannuth in Ramaḍān, as the reclusion of Muhammad to the Cave of Hirā's in the same month shows.

Tahannuth is unclear in terms of significance and concept; many Muslim scholars have explained it as worship (tacabbud) and selfjustification (tabarrur). ${ }^{39}$ According to a narrative related by Ibn Rāhawayh (d. 238/853) and Abū Nu'aym al-Ișfahānī (d. 430/1038) through 'A''isha, the Prophet's experience of tahannuth in the Cave of Hirā') during Ramaḍān is explicitly described as $i^{\dagger} t i k a \bar{a}$ (anna Rasūl Allāh nadhara an ya 'takifa shahr ${ }^{a n}$ bi-Hirā')..$^{40}$

Pursuant to a citation by Abū l-Faraj al-Halabī (d. 1044/1635) from 'Ubayd ibn 'Umayr, the Prophet used to stay in the Cave of Hirā' for approximation one month every year. This ritual was a type of continuation of tahannuth practiced by devout Qurayshites during the Days of Ignorance. The Prophet's first retreat to Hirā' coincided with the times of his marriage to Khadija. In those days, like his grandfather 'Abd al-Mutțalib, he used to be engaged in charities, such as providing food for the poor. During the Days of Ignorance, Hirā’

38 See Abū l-Faraj Zayn al-Dīn 'Abd al-Raḥmān ibn Aḥmad Ibn Rajab al-Ḥanbalī, Lațā'if al-ma'ārif fì-mā li-mawāsim al-'ām min al-wazāàif (ed. Yāsīn Muhammad al-Sawwās; $5^{\text {th }}$ edn., Damascus \& Beirut: Dār Ibn Kathīr, 1999), 283388.

39 For further information see M. J. Kister, "et-Tehannüs: Kelime Anlamı Üzerine Bir Araştırma" (translated into Turkish by Ali Aksu), Tasavvuf: Ilmî ve Akademik Araştırma Dergisi 2/4 (2000), 215-230.

40 Abū Ya'qūb Isḥāq ibn Ibrāhīm ibn Makhlad Ibn Rāhawayh, Musnad Isḥāq ibn Rāhawayh (ed. 'Abd al-Ghafūr ibn 'Abd al-Ḥaqq Ḥusayn Burr al-Balūshī; Medina: Maktabat al-Īmān, 1990-1991), III, 970-971; Abū Nu'aym Aḥmad ibn 'Abd Allāh ibn Isḥāq al-Iṣfahān̄i, Dalā'il al-nubuwwa (eds. Muḥammad Rawwās Qal'ajī and 'Abd al-Barr 'Abbās; 2 2nd edn., Beirut: Dār al-Nafā’is, 1986), I, 215. 
was known as a type of hermitage and place of worship for charitable persons; consequently, it had established place for the poor. ${ }^{41}$

Pursuant to these data, the Prophet's self-confinement during Ramadān never had a technical purpose, such as reviewing of the Qur'ān's text or, as claimed in several sources, elimination of invalid verses; instead, he retreated to be alone with Allah and to surrender to Him so as to fill himself with spiritual power. Muhammad must have contemplated and questioned himself about the heavy responsibilities the Qur'ān placed on him; indeed, these facts are emphasized in Q 73:1-10.

In light of the foregoing assessments, narratives about the presentation might be fabricated so as provide ground for the authenticity of the Qur'ān's text and the prescription of its arrangement according to divine ordinance (tawqịfi) under the inspiration of the self-confinement ( $\left.i^{c} t i k \bar{a} f\right)$ ritual during Ramaḍann. Self-confinement definitely includes a soft of review; nevertheless, despite the narratives about the presentation, this review is not about correction, redaction or proofreading of the Qur'ān's text but about revision by Muhammad of his responsibilities as prophet and messenger.

As a narrative from Zayd ibn Thābit, the best known and reliable riwāya about the textualization process of the Qur’ān, clearly asserts, Muhammad never conceived the Qur'ān as a text to legislate for future Muslims. Otherwise, it would be impossible to explain the following response by Abū Bakr upon 'Umar's suggestion to collect the Qur’ān: "How can I carry out an affair that Rasūl Allāh did not?!" This is why al-Zarkashī (d. 794/1392) made the following remark: the Qur'ān's verses were not transformed into a collection of sheets between two covers (mushaff) during the lifetime of Muhammad. Because such a process would require continuous changes in the arrangement of the text, the collection of the Qur'ān as a written text was delayed until the end of the descent period. Following the death of the Prophet, the collection and reproduction were performed by

41 Abū l-Faraj Nūr al-Dīn 'Alī ibn Burhān al-Dīn ibn Ibrāhīm ibn Aḥmad al-Ḥalabī, Insān al-'uyūn fì sìrat al-Amìn al-Ma'mūn (al-Sìra al-Halabiyya), (3 ${ }^{\text {rd }}$ edn., Cairo: al-Mațba‘a al-Azhariyya, 1932), I, 271-272. 
Companions such as Abū Bakr and 'Uthmān. ${ }^{42}$

During the thirteen-year Mecca period, there was no solid information about when and how the Qur'ān was first textualized, let alone whether the presentation actually occurred between the Prophet and Gabriel every Ramaḍān. Apparently, Muslim scholars constructed a retrospective history to prove the traditional conviction that not a single word in the Qur'ān changed until our day; thus, they opted for a history of the Qur'ān without allowing for any gaps or obscurities.

For us, the arrangement of verses into smaller chapters, mostly descended in Mecca, was made according to divine ordinance (tawaîfi) as the interval letters (fāșila) and rhymes (saj) show. Moreover, the Qur'ān is a text said during prayers such as șalāt since the very beginning. Therefore, many chapters and verses must be said in a certain order at least. Accordingly, the verses and/or verse groups in more voluminous chapters about multiple, extended incidents, such as al-Baqara, Āl 'Imrān, and al-Nisā', were probably arranged in an ijtiha $\bar{a} d \bar{\imath}$ (through independent reasoning) manner, in other words, at the discretion of the copiers.

This argument seems even stronger because many verses in longer chapters, such as al-Baqara, Āl 'Imrān, al-Nisā'), and al-Mā'ida, for example, Q 2:238-239 have a wording and meaning structure unsuitable for establishing a connection via priority-subsequence. The same possibility includes disputes during the collection and reproduction of the Qur'ān regarding the determination of the places of verses, such as Q 33:23 and/or Q 9:128-129, which are subsequently noticed or uttered near a single Companion, or questions about the probability of arranging such verses as a separate chapter. ${ }^{43}$

Various narratives through the Companions have indicated that the Qur'ān was generally revealed in groups of four or five verses and passages. According to hundreds of narratives about the reasons for its descent, the verses were sent down in separate passages, in

\footnotetext{
42 Al-Zarkashī, al-Burhān, I, 262.

43 See al-Ṭabarī, Tafsīr al-Ṭabarī, I, 49; Abū Bakr 'Abd Allāh ibn Sulaymān ibn alAsh'ath Ibn Abī Dāwūd, Kitāb al-mașāḥif (ed. Arthur Jeffery; Leiden: E. J. Brill, 1937), 30-31.
} 
connection with incidents during the revelation period. Therefore, the arrangement of verses in voluminous chapters such as al-Baqara and Âl 'Imrān might have been established by bringing together various passages about a main theme as much as possible. For example, it is well known that first 100 verses in al-Baqara are about the Jews of Medina, while the first 80 verses in Āl 'Imrān treat the Christians of Najrān. ${ }^{44}$ Thus, verses in the aforementioned sections of al-Baqara and Āl 'Imrān might, at first glance, address different themes; nevertheless, because the main theme and addressees are the same, it was considered reasonable to arrange them with a type of interior integrity, and the organization must have been realized in this manner.

This evaluation also applies for several voluminous Madanī chapters, such as al-Nisā̄a al-Mā’ida, al-Nūr, al-Aḥzāb, and others. For instance, chapter al-Aḥzāb was sent down in various passages coincident with numerous incidents over a couple of months: it covers the smear campaign by polytheists, hypocrites, and the Jews of Medina against Muhammad and believers at the time of Battle of the Trench (Ghazwat al-khandaq), also known as the Battle of Confederates (Ghazwat al-aḩzāb), which began on 7 Shawwāl 5 AH (1 March 627) and ended on 1 Dhū 1-Qa'da 5 AH (24 March 627). Although the chapter is primarily about the Battle of the Trench, it also treats, as its name suggests, in various verse groups (between, for example, 30 and 34 and between 5 and 62), the marriage of the Prophet to Zaynab bint Jaḥsh, the Battle of Banū 1-Mușțaliq (2 Sha'bān 5 AH/27 December 626 - 1 Ramaḍān 5 AH/24 January 627), and the disturbance due to the Ifk incident.

Reports of the determination by Muhammad of the exact place of verses in relevant chapters are also controversial and require a cautious approach. Hence, it does not seem reasonable to rely on narratives such as "Whenever several verses were revealed to Rasūl Allāh, he called one of the revelation clerks and told them, 'Place these verses in that part of the chapter with so-and-so theme" ${ }^{45}$ or "Rasūl Allāh said: 'Gabriel came to me and ordered me to place a

\footnotetext{
44 Abū Muḥammad Jamāl al-Dīn 'Abd al-Malik Ibn Hishām, al-Sīra al-nabawiyya (eds. Mușțafā al-Saqqā, Ibrāhīm al-Abyārī, and 'Abd al-Ḥafīẓ Shalabī; Beirut: Dār al-Khayr, 2004), II, 131; al-Ṭabarī, Tafsīr al-Ṭabarī, III, 162.

45 Ibn Hajar al-`Asqalānī, Fatḥ al-bārī, IX, 29, 52.
} 
verse into that part of so-and-so chapter" "46 to claim that the Prophet personally established the arrangement of all of the verses, on the one hand, while arguing that, during the collection process in the time of Abū Bakr, 'Umar and Zayd ibn Thābit went to the mosque and said, "Whoever has a written verse with him should bring them to us together with two witnesses," on the other hand, does not seem reasonable.

If the Prophet, in person, determined the place of each verse of the Qur'ān in the relevant chapter, the arrangement of the Qur'ān should have been arranged at the time of revelation, and the Qur'ān would have been an organized text as early as during Muhammad's lifetime. Nevertheless, the collection process, which began with the suggestion by 'Umar and with the initially hesitative but later convicted attitude of Abū Bakr, shows that this was not the case.

Consequently, we believe that the conventional opinions and general acceptance about arrangement were only determined afterward. Moreover, according to some narratives, 'Umar and Zayd ibn Thābit collected Qur’ān verses from palm branches, fine stones, and memories of people on the condition of the testimony of two men, while according to others, Abū Bakr assigned twenty-five men from Quraysh and fifty among Anșār and ordered them, "Put the

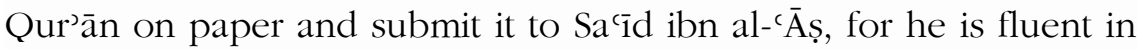
Arabic.” ${ }^{47}$

In contrast, some other narratives indicate that the verses were arranged in $i j t i h \bar{a} d \bar{l}$ and not tawqīfi manner. For example, one narrative reads that Khuzayma ibn Thābit or Abū Khuzayma al-Anșārī brought two verses, whereupon 'Umar said, "If there were three of these verses, I would turn them into a new chapter; search for a (suitable) chapter in the Qur'ān and place these two verses in it." Ibn Hajar al-'Asqalānī (d. 852/1449) offered the following assessment: "As this narrative apparently puts forth, the Companions arranged/amended verses in chapters pursuant to their own conceptions. However, other narratives show that the Companions

\footnotetext{
46 Ahmad ibn Hanbal, al-Musnad, IV, 218.

47 Abū l-'Abbās Aḥmad ibn Abī Ya'qūb ibn Ja'far ibn Wahb al-Ya'qūbī, Tārìkh alYa'qūbì (ed. 'Abd al-Amīr 'Alī Mahnā; Beirut: Sharikat al-A'lamī li-l-Maṭbū'āt, 2010), II, 22.
} 
had no discretion about the arrangement of verses except for divine ordinance (tawqīf).” ${ }^{48}$

Another narrative relates that Zayd ibn Thābit undertook a lengthy search for Q 33:23 and finally found it from Khuzayma; ${ }^{49}$ yet another narrative allows for the following indications by Yūsuf ibn Māhak: "I was with ' $\overline{\mathrm{A}}$ 'isha, the mother of believers. Then a man from Iraq appeared and said, 'O, the mother of believers! Show me your own muş̣haf. ' $\overline{\mathrm{A}}$ 'isha asked why, whereupon the 'Irāqī responded, 'I must compile/arrange the Qur'ān pursuant to your muṣaf because the Qur'ān is read without proper arrangement and order.' ' $\overline{\mathrm{A}}$ 'isha gave the following answer: 'You can read or recite regardless of which chapter (sūra, passage) in the Qur'ān preceded it; that is all right."'50

For Ibn Hajar, the question by the 'Irāqi to ' $\overline{\mathrm{A}}$ 'isha is about the arrangement of chapters, before adding that it might also be about the individual determination of verses in each chapter, based on the phrase "'A')'isha had him write verses in chapters (fa-amlat 'alaybi $\bar{a} y$ al-suwar)" in the hadith. ${ }^{51}$

Narratives about the tawqi fi character of arrangement of verses are authentic in terms of certitude; however, they might be specifically about the arrangement of several passages or verse groups within voluminous chapters. Indeed, it seems neither realistic nor persuasive that Muhammad ordered individual assignments for each verse in chapters as voluminous as al-Baqara, Āl 'Imrān, al-Nisā', al-Mā'ida, alTawba, etc., which were sent down at various times during ten-year Medina period, even before their completion.

The view on the $i$ itih $\bar{a} d \bar{\imath}$ arrangement of verse groups in larger chapters can also be refuted, based on the Prophet having been used to reciting the Qur'ān in prayers and that he could not have done so if the verses were not in a certain order. Nonetheless, remember that these chapters were not sent down at once; therefore, neither the Prophet nor the Companions recited them as a whole from the very beginning. In addition, Muhammad reportedly advised keeping recital during prayers as short as possible; accordingly, he most

\footnotetext{
48 Ibn Hajar al-`Asqalānī, Fatḥ al-bārī, IX, 20.

49 Al-Bukhārī, "Faḍā̄il al-Qur’ān," 3.

50 Al-Bukhārī, "Faụāìl al-Qur’ān," 6.

51 Ibn Hajar al-'Asqalānī, Fatḥ al-bārī, IX, 50.
} 
probably did not recite chapters of dozens of pages, such as alBaqara, Āl 'Imrān, al-Nisā'), and al-Mā'ida, during șalāt, especially with the community.

Regarding the arrangement of verses, in agreement with the opinions of most scholars, Muṣhaf, which begins with al-Fātiha and ends with al-Nās, was arranged through $i j t i h \bar{a} d$ by the Companions. ${ }^{52}$ Under this arrangement, al-Fātiha is placed in the beginning like a soft of preface, while the subsequent 113 chapters, we can say, are ordered from longer to shorter or larger to smaller. Nonetheless, some scholars have defended that the arrangement of chapters is not $i$ itibādi but tawqīfi. The narratives, which include the information that the Prophet classified chapters as al-sab al-țiwāl (seven long chapters), mi'un (those with approximately one hundred verses), and mathan $\bar{\imath} \bar{\imath}$ (with fewer than a hundred verses) ${ }^{53}$ seem to support the tawqif $\bar{i}$ argument; nevertheless, such narratives should also be cautiously treated. If the organization of chapters depended on the notification and determination by Muhammad, asked about placing the chapter al-Anfāl in the eighth position although it is shorter and smaller than al-Tawba, as well as the lack of Basmala in the beginning of the latter, 'Uthmān would not have given the following answer reported by al-Bāqillānī:

Because the chapters al-Anfāl and al-Tawba are similar in terms of content (theme and expression), I considered al-Tawba to be a continuation of al-Anfāl; Rasūl Allāh passed away before giving us any explanations about these chapters. Therefore, I placed the two consecutively in muṣ, af but did not separate them with Basmala. ${ }^{54}$

Conversely, there are several narratives about disputes over some verses, such as Q 33:23 and Q 9:128-129, during the activities of the copying committee under the presidency of Zayd ibn Thābit; some of these narratives are given in al-Jām $\bar{\imath}^{c}$ al-șaḥiḥ by al-Bukhārī (d. 256/870) and Muslim (d. 261/875), which are considered authentic

52 Abū Jacfar Aḥmad ibn Ibrāhīm Ibn al-Zubayr al-Gharnāṭi, al-Burhān fì tartīb suwar al-Qur'ān (ed. Muhammad Sha'banī; n.p.: al-Mamlaka al-Maghribiyya Wizārat al-Awqāf wa-l-Shu'ūn al-Islāmiyya, 1990), 182; al-Suyūṭī, al-Itqān, I, 194.

53 Abū 'Ubayd al-Qāsim ibn Sallām, Faḍ̄à'il al-Qur'ān wa-ma'ālimub ${ }^{\bar{u}}$ wa$\bar{a} d \bar{a} b u b^{\bar{u}}$ (ed. Ahmad ibn 'Abd al-Wāḥid al-Khayyāṭ̂i; n.p.: al-Mamlaka alMaghribiyya Wizārat al-Awqāf wa-l-Shu’ūn al-Islāmiyya, 1995), II, 29.

54 Al-Bāqillānī, al-Intiṣārr, I, 281-282. 
and prestigious works in the Sunnī tradition. In addition, there are reportedly authentic/reliable narratives about the presence of the "raim verse" and some texts that are allegedly verses. Accordingly, it is known that the private muṣhaf of Ibn Mas'ūd, the famous Companion, did not include the chapters of al-Fātiha and alMu'awwidhatayn (al-Falaq and al-Nās), while in the private mușhaf of Ubayy ibn $\mathrm{Ka}^{\mathrm{c}} \mathrm{b}$, there are Qunūt prayers, as well as two other chapters, called al-Khalc and al-Hafd, in addition to 114 chapters. Moreover, it is controversial whether al-Fīl and Quraysh, al-Duhāa and al-Inshirāh collectively constitute one chapter or are individual chapters. ${ }^{. \dot{5}}$

In addition, the position of Basmala in muṣhaf and the lack of Basmala at the beginning of al-Tawba have always been controversial issues. Moreover, there have been disputes about the number of verses in the Qur'ān and in individual chapters. According to relevant sources, the Qur’ān consists of 6000, 6204 (counted by experts in alBașra), 6210 (counted by experts in Mecca, via Ubayy ibn Ka'b), 6214 (final count by experts in Medina), 6216 (via Ibn 'Abbās), 6217 (first count by experts in Medina), 6219, 6225, 6226 (counted by experts in Damascus), and 6236 (counted by experts in al-Kūfa) verses. ${ }^{56}$

For al-Suyutți, the number of verses in all of the chapters is controversial pursuant to different counts by experts in Mecca, Medina, Damascus, al-Bașra, and al-Kūfa, except for forty chapters, so much so that there are two different enumerations in Medina, based on Abū Ja'far Yazīd ibn al-Qa' ${ }^{\prime} \bar{a}^{\prime}$ (d. 130/748) and Ismā'îl ibn Jacfar Ibn Abī Kathīr (d. 180/797), respectively. The former is called the "first enumeration by experts in Medina ('adad abl al-Madina alawwal)," while the latter is known as the "final/later enumeration by experts in Medina ( $a d a d$ abl al-Madina al-akbir)." According to the chain of narratives, the enumeration by experts in Mecca is attributed to the Companion Ubayy ibn Kacb, the enumeration in Damascus is attributed to Abū 1-Dardā', the enumeration in al-Kūfa is attributed to 'Alì ibn Abī Țālib, and the enumeration in al-Bașra is attributed to the

\footnotetext{
55 Al-Zarkashī, al-Burhān, I, 251; al-Suyūțī, al-Itqān, I, 204-217.

56 Abū 'Amr 'Uthmān ibn Sa'̄id al-Dānī, al-Bayān fì 'add āy al-Qur'ān (ed. Ghānim Qaddūrī al-Ḥamad; Kuwait: Manshūrat Markaz al-Makhṭūṭāt wa-1-Turāth wa-1Wathā'iq, 1994), 79-82; al-Zarkashī, al-Burhān, I, 249.
} 
follower (tābicî̀) Abū 1-Mushajiar 'Āșim al-Juhdarī (d. 128/746). ${ }^{57}$ In the light of all these data, the number of verses in chapters is controversial even among the Companions.

Although the Qur'ān's verses reportedly descended at different times for different reasons, and many verse groups, particularly in longer chapters, are disconnected in terms of expression and relation, some exegetes, such as Fakhr al-Dīn al-Rāzī (d. 606/1210) and alBiqā̄ì̄ (d. 885/1480) in the classical period and Amīn Aḥsan Iṣlāhī (d. 1997) in the modern era, have asserted that each verse has a strict relationship with another verse or group of verses, and each chapter has a strict bond to another chapter or chapters pursuant to literal $i{ }^{\prime} \bar{a} z$, which we consider to be an exaggerated approach; these exegetes have even developed a sub-discipline called al-tanāsub bayna l-āyatt wa-l-suwar or tanāsub al-āy wa-l-suwar (harmony among the verses and chapters of the Qur'ān) within the scope of sciences of the Qur'ān ('ulūm al-Qur'àn). In return, al-Shawkānī (d. 1250/1834) and some other exegetes have considered these efforts, such as comprehensive studies about tanāsub by al-Biqā $\overline{\hat{1}}$, to be useless preoccupations, indicating that they are "unacceptable views about the book of Allah."

Following the anecdote about Adam and heaven in Q 2:30-39, verse 40 begins to treat the story of Moses and the Israelites; alShawkānī extensively analyzed the relationship between these two groups of verses. According to him, the Qur’ān's verses, which were sent down for twenty-years with regard to countless incidents, naturally comprise controversies rather than connections between them. Different verses might declare the same thing to be harām and balāl in different periods; some verses are about believers, while some are about disbelievers, past communities, or people and groups at the time of revelation; some verses treat worship, whereas some deal with practical issues; some are about incentives while some seek to frighten, and some treat torment and reward. Al-Shawkānī argued that not only the longer and voluminous chapters but also the medium-sized chapters were sent down upon various incidents pursuant to historical context.

57 Al-Dānī, al-Bayān, 67-71; al-Suyūṭī, al-Itqān, I, 211. Abū 'Amr al- Dānī (d. 444/1053) also mentions a seventh enumeration extracted from Khālid ibn Ma'dān (d. 103/721) the famous tābi ‘̄ from Homs. See al-Dānī, al-Bayān, 70. 
According to al-Shawkānī, the search for a relationship between verses or chapters is based on the assumption that the revelation of the Qur'ān follows a path in parallel with the muṣaf arrangement. However, anyone more or less interested in and informed about the Qur'ān knows that this is not the case. Chapters like al-'Alaq, alMuddaththir and al-Muzzammil are reportedly among the earliest to descend; they are, however, located in the latter parts of the muṣhaf.

It is well known that al-'Alaq, al-Muddaththir and al-Muzzammil were the first revealed chapters; they are, however, located in the latter parts of the book. Therefore, the search for relationships between verses and chapters is based not on the revelation order of the Qur'ān but on the order established by the Companions during the activities of collection and dictation. Consequently, it is useless and barren to preoccupy oneself with the problem of tanāsub al-āy wa-l-suwar. Allah characterized the Qur'ān in Arabic and sent his kalām in line with the linguistic traditions of Arabs. For instance, an Arabian speaker touches upon various subjects during a speech. The modes of address, expression, and style in the Qur’ān are similar. ${ }^{58}$

The Qur'ān, as a whole, is evidently a consistent and related text in itself. Indeed, the greatest objective and cause for the Qur'ān are unity and justice, while it essentially seeks to abolish polytheism and cruelty. The Qur'ān is related to these two themes from beginning to the end. Nevertheless, the relationship indicated in 'ulüm al-Qur'ān literature regards the semantic connection between the passages of a text written at a desk. Such connections can be established between many verses and even successive chapters. However, there is no such necessity within the arrangement of the book; in addition, connections discovered through reasonable deductions are not necessarily signs of literal inimitability ( $i c j \bar{a} z$ ).

\section{Question of Nuzūl Order}

Despite all of the disputes over the collection of the Qur'ān, it is beyond any doubt that the mushaf was arranged at the time of 'Uthmān, and since then, this arrangement has been conveyed successively through recital and writing. In contrast, it is impossible

58 Abū 'Abd Allāh Muḥammad ibn 'Alī ibn Muḥammad al-Shawkānī, Fatḥ al-qadīr al-jāmi' bayna fannay al-riwāya wa-l-dirāya min 'ilm al-tafsìr (Beirut: 'Ālam alKutub, n.d.), I, 72-73. 
to say the same thing about the revelation order of the Qur'ān. Relevant references provide various revelation orders attributed to Companions, Followers or subsequent scholars, such as 'Alī ibn Abī Ṭālib, 'Abd Allāh ibn 'Abbās and Nu'mān ibn Bashīr, or even to Jābir ibn Zayd (d. 93/712), al-Ḥasan al-Bașrī (d. 110/728), Ibn Shihāb alZuhrī (d. 124/742), Ja‘far al-Șādiq (d. 148/765), or al-Wāqidī (d. $159 / 776$ ?)..$^{59}$ Some recent studies have discussed a revelation order attributed to 'Uthmān; nevertheless, no references have been provided for such arrangement. ${ }^{60}$

Interestingly enough, the arrangement order attributed to 'Uthmān is identical to the arrangement that constitutes the basis of al-Tafsir al-badith by 'Izzat Darwaza. Darwaza, however, does not attribute this arrangement to 'Uthmān; instead, he provides notes of information on the chapters with regard to time and place of revelation in the muṣhaf written by the calligrapher Muștafā Naẓif Kadırgalī and published by 'Abd al-Hamīd Ahmad Hanafī, together with a statement by the Egyptian Ministry of the Interior and approval of Egyptian Qur’ān scholars.

This muṣhaf was also published a few times in Istanbul before and after the rule of Sultan 'Abd al-Hamid II, before becoming popular

See Abū 'Abd Allāh Muḥammad ibn Ayyūb Ibn al-Ḍrays, Fad̄ā'il al-Qur'ān wamā unzila min al-Qur'ān bi-Makka wa-mā unzila bi-l-Madīna (ed. 'Urwa Badīr; Damascus: Dār al-Fikr, 1987), 33-34; Abū l-Faraj Muḥammad ibn Isḥāq Ibn alNadīm, al-Fihrist (ed. Ibrāhīm Ramađ̣ān; $2^{\text {nd }}$ edn., Beirut: Dār al-Macrifa, 1997), 42-43; Abū l-Qāsim al-Ḥasan ibn Muḥammad ibn Ḥabīb al-Nisābūrī, Kitāb altanbīh 'alā fậl 'ulūm al-Qur'ān (ed. Muhammad 'Abd al-Karīm Kāẓim al-Rāọīi), al-Mawrid: Majalla Turāthiyya Fașliyya 17/4 (1988), 307; Abū Bakr Aḥmad ibn al-Husayn ibn 'Alī al-Bayhaqī, Dalā'il al-nubuwwa wa-ma'rifat aḅwāl șāḥib alsharī'a (ed. 'Abd al-Mu'țī Amīn Qal'ajīi; Beirut: Dār al-Kutub al-'Ilmiyya, 1988), VII, 142-144; al-Dānī, al-Bayān, 135; Abū 'Alī al-Fạ̣l ibn al-Ḥasan al-Ṭabarsī, Majma' al-bayān fì tafsīr al-Qur'ān (Beirut: Dār al-Kutub al-'Ilmiyya, 1997), X, 164-165; Abū l-Fatḥ Tāj al-Dīn Muḥammad ibn 'Abd al-Karīm al-Shahrastānī, Mafātīh al-asrār wa-mașābīh al-abrār (ed. Muḥammad Ādharshab; Tehran: Mīrāth Maktūb, 2008), I, 19-13; al-Zarkashī, al-Burhān, I, 193; al-Suyūṭī, al-Itqān, I, 81-83; Arthur Jeffery (ed.), Muqaddimatān fì 'ulūm al-Qur'ān: wa-bumā muqaddimat Kitāb al-mabānì wa-muqaddimat Ibn 'Ațiyya (Cairo: Maktabat alKhānjī, 1954), 8-13; Ḥātim Ṣāliḥ Ḍāmin, Nuṣūṣ muḥaqqaqa fì 'ulūm al-Qur'ān al-karìm (Baghdad: Markaz Jamā'at Mājid li-1-Thaqāfa, 1991), 88-93.

60 İsmail Cerrahoğlu, Tefsîr Usûlü (Ankara: Türkiye Diyanet Vakf1, 1983), 86-87. 
across the entire Muslim world. The same muṣhaf was published several times in Egypt. Darwaza explained why he based the arrangement of descent on this version as follows: "In this Muṣhaf, the indications of the succession of a certain chapter after another prove that the committee of scholars who examined and approved the version have assessed various narratives and determined preferences among them before deciding on the order of revelation." ${ }^{61} \mathrm{He}$ also emphasized that some chapters are contradictory to the mentioned arrangement with regard to the time of revelation.

The rough uniformity of various revelation arrangements in 'ulūm al-Qur'ān, exegeses and history books could be considered evidence for the sameness of their sources. Most probably, this source is Ibn 'Abbās. Indeed, various works have attributed different arrangements of revelation to Ibn 'Abbās. The arrangements attributed to Jābir ibn Zayd and Abū Ṣālị̣ also likely belong to Ibn 'Abbās because Jābir ibn Zayd was a disciple of Ibn 'Abbās who praised him, saying "Once you have Jābir with you, why do you come to me to ask questions?" 22 Regarding Abū Ṣaliḥ 'Abd Allāh ibn Ṣaliḥ, he was the most reliable narrator of several narratives about exegesis that are attributed to Ibn 'Abbās.

It is difficult to rely on the accuracy and validity of the revelation order in classical sources. As Darwaza indicated, there is no revelation order that extends over the lifetime of the Prophet. In addition, information in narratives makes contradictory statements about the Makkī or Madanī character of several chapters. According to some narratives, al-Ra'd, al-Haiji, al-Raḥmān, al-Insān, al-Zalzala, alFalaq, al-Nās, al-Ikhlāṣ, al-Kawthar, Quraysh, al-'Așr, al-'Ādiyāt, alQadr, al-Muțaffifīn and al-Fātiḥa are classified as Makkī, while some others considered them Madanī. ${ }^{63}$

Such disputes arise from the insufficiency of information about when and upon which incident the chapters and verse groups were

61 Muḥammad 'Izzat Darwaza, al-Tafsīr al-ḥadīth (Tunis: Dār al-Gharb al-Islāmī, 2008), I, 12-14, 17.

62 Abū 'Abd Allāh Shams al-Dīn Muḥammad ibn Aḥmad ibn 'Uthmān al-Dhahabī, Siyar a ‘̄àm al-nubalā' (eds. Bashshār 'Awwād Ma'rūf et al.; $2^{\text {nd }}$ edn., Beirut: Mu’assasat al-Risāla, 1981-1988), IV, 482.

63 Darwaza, al-Tafsìr al-ḥadìth, I, 125. 
sent down. Moreover, not all of the verses of the Qur'ān were sent for definite reasons. Pursuant to the findings of scholars, only approximately 500 verses descended due to a particular reason for revelation. For Shāh Walī Allāh al-Dihlawī (d. 1176/1762) and certain other scholars, a large number of narratives that relate motives of revelation in exegesis do not provide the actual reason for the revelation; instead, they are exegesis-related narratives to establish connections between verses and subsequent incidents or to interpret such incidents in light of the verses. ${ }^{64}$

Commentaries and Islamic biographies provide very little information about the incidents that led to the revelation of particularly the Makki chapters and verses or the historical environments around these incidents because, during his thirteen years in Mecca, Muhammad struggled for survival against polytheists and thus considered the Qur'ān as divine guidance to transform man and society in daily life, rather than a text to be legislated for future Muslim generations. The same interpretation also pertains to his Companions. Moreover, the generation of Companions never construed the Qur'ān's revelation to be a text independent from the Prophet and his Sunna.

Muhammad did not consider the Qur’ān to be a text to be collected into a book and legislated for posterity in this format. One of the strongest pieces of evidence for this fact is the famous narrative of Zayd ibn Thäbit, which tells how the activity of the collection of the Qur'ān began during the caliphate of Abū Bakr. According to the narrative, because a great number of hāfiz Companions were martyred during the Battle of al-Yamāma and other wars, 'Umar feared that the Qur'ān might disappear from public memory, whereupon he offered to Caliph Abū Bakr to collect the Qur'ān as a written text. Abū Bakr was, however, initially hesitant regarding such an activity, asking "How could I do something that Rasūl Allāh did not?" 65

64 Abū 'Abd al-'Azīz Quṭb al-Dīn Shāh Walī Allāh Aḥmad ibn 'Abd al-Raḥīm alDihlawī, al-Fawz al-kabīr fì uṣūl al-tafsīr (Damascus: Dār al-Ghawthānī li-1Dirāsāt al-Qur’āniyya, 2008), 69-70.

65 Al-Bukhārī, "Faụ̂āil al-Qur’ān," 3. 
Regarding the arrangement of revelation, we must be doubtful about the soundness of different revelation arrangements, which, in particular, belong to Ibn 'Abbās. As is known, commentaries that based on narratives provide many incompatible reasons from Ibn 'Abbās for revelations about the same verse; similarly, there are many controversial explanations for numerous verses and wordings. Narratives including that of Ibn 'Abbās have created significant confusion in exegeses of the Qur'ān because they relate several explanations for the interpretation of almost every verse; accordingly, al-Imām al-Shāficī (d. 204/820) had to indicate that, among the information from Ibn 'Abbās, nothing is solid but for approximately a hundred news (khabar). ${ }^{66}$ Consequently, although critics of hadith and narratives attempted to evaluate, in terms of documentation/authenticity, exegetic lines attributed to Ibn 'Abbās, such studies could not eliminate the aforementioned confusion. ${ }^{67}$

Indeed, it is unclear whether Ibn 'Abbās obtained information about the revelation order of the Qur'ān's chapters from the Prophet or from a Companion such as 'Alī or whether he established the arrangement personally based on his own knowledge and competence. If the revelation arrangements provided by Ibn 'Abbās were based on his personal ideas and convictions, they would be, as Muhammad Husayn Țabāṭabā'̄i (d. 1981) noted, valuable arrangements but reliable only in a self-proclaimed manner. ${ }^{68}$ In contrast, considering that Ibn 'Abbās was born three years prior to the Hegira and was a 12-to 13-year-old boy at the time of the death of Muhammad, he is unlikely to have witnessed the times or circumstances of the revelation of the Qur'ān's chapters.

In brief, various revelation arrangements indicated in classical sources cannot provide precise or final information about the chronology of the descent of chapters. At this point, one can only provide rough and general information about whether a chapter is Makkī or Madanī. However, for such a categorization, it is necessary not to based it on individual narratives but to attempt to establish a

\footnotetext{
66 Al-Suyūțī, al-Itqān, II, 1233.

67 See Muhammad Husayn al-Dhahabī, al-Tafsīr wa-l-mufassirūn (Beirut: Dār alArqam, n.d.), I, 53-56.

68 Muhammad Husayn Ṭabātabā'̄̄, İslam'da Kur'an (translated into Turkish by Ahmed Erdinç; Istanbul: Bir Yayıncılık, 1988), 129.
} 
relationship between the information in relevant narratives, social circumstances during the Mecca and Medina periods, and the content of chapters; accordingly, one should search and scan earlier biographies and battle histories.

Conversely, the revelation arrangement of many, particularly Madanī, chapters includes interpenetration. For instance, several references have indicated al-Baqara to be the first chapter to be sent down in Medina. In contrast, some narratives have indicated verses 278,281 , and 282 of al-Baqara to be the last verses revealed. ${ }^{69}$ Therefore, al-Baqara was sent down in passages over ten-year period in Medina; in the process, the revelation of chapters such as $\bar{A} l$ 'Imrān, al-Nisā̄, al-Mā’ida, al-Anfāl, and al-Tawba also continued in a similar manner.

Moreover, during the first years after the Hegira, many significant incidents, such as the change of Qibla (2 AH), the command of fasting during Ramaḍān (2 AH), Expeditionary force (sariyya) of Baṭn al-nakhla (2 AH), Patrol of al-Abwā' (2 AH), Patrol of Buwāt (2 AH), Patrol of Dhū 1-'Ushayra (2 AH), Expulsion of Banū Qaynuqā̄ (2 AH), Battle of al-Sawīq (2 AH), Battle against Banū Ghațafān (3 AH), Battle of Banū Sulaym (3 AH), Battle of Uhud (3 AH), Battle of Hamrā' alasad (3 AH), Expedition of al-Rajī‘ ( $4 \mathrm{AH}$ ), Expedition of Bi’r Ma'ūna ( $4 \mathrm{AH}$ ), and Siege of Banū Nadịir (4 AH), occurred, and verses about some of these events are scattered over various chapters, such as alBaqara, Āl 'Imrān, al-Anfāl, and al-Ḥashr.

For a complete and flawless revelation order, verses and various verse groups about foregoing incidents should be chronologically sorted; however, we lack sufficient and satisfactory information to provide such an arrangement. In addition, it is arguable how useful it would be to arrange a Qur'ān text without integrity, in contrast to the current mushaf organization. In brief, the conventional arrangements, which position al-Baqara first among the Madanī chapters, are mostly arbitrary and have no function other than providing a rough idea about the revelation process of the Qur'ān.

For us, it is vital to know deeply the attitudes of the Prophet for better understanding of transformative messages for individuals and the community in the Qur’ān, as well as to analyze the Book in this

69 See al-Suyūṭī, al-Itqān, I, 86-87; Ibn 'Aqīla, al-Ziyāda wa-l-iḥsān, I, 180. 
regard, because the message of the Qur'ān is interpenetrated with the life experiences of Muhammad and his Companions. Therefore, knowledge about the true stories of addressees in the beginning is very important for a better understanding of the Qur'ān's messages for humanity and for a higher sense of what the Qur'ān wants us to feel. However, such understanding and conception cannot be obtained through rough arrangements about revelation; therefore, it is impossible to achieve such an understanding through the reading of translations prepared pursuant to such a revelation order. For this purpose, a scientific exegesis, which emphasizes the attitude of the Prophet and incidents in his lifetime, seems necessary.

\section{History of Studies on the Nuzül Order}

There are multiple revelation arrangements in the tafsīr and 'ulüm al-Qur'a $\bar{n}$ literature; in the classical era, this variety was overlooked and considered unnecessary, and the muṣ, af arrangement was used as a basis. Nevertheless, the introduction to exegeses of chapters included brief references regarding whether the relevant chapter is Makkī or Madanī. Connections with the non-textual context of the Qur'ān were mostly established through narratives about issues such as asbāb al-nuzūl and nāsikh-mansūkh; passages lacking any narrative about the reason for their descent were generally interpreted in consideration of history and articulation.

Obedience to the muṣaf arrangement in the classical exegetic tradition might have been due to the holiness attributed to the muṣhaf arrangement in a sense and acceptance of this arrangement as a type of miracle pursuant to relevant indications in the culum alQur'a $\bar{a}$ literature; in contrast, it might be in line with the principle in tafsir and fiqh that "reliance is based not on the particularity of cause but on the universality of wording."

Recently, the process and order of nuzūl of the Qur'ān have become a popular and interesting subject in the Muslim world. One of the probable factors underlying this tendency might be the influence of Orientalist approaches on Qur'ānic studies as a reflection of the multidimensional defeat of the Muslim world by the West. Orientalist works by, for example, Gustav Weil (d. 1889), William Muir (d. 1905), Theodor Nöldeke (d. 1930), Hartwig Hirschfeld (d. 1934), Richard Bell (d. 1952), and Régis Blachère (d. 1973), have mostly considered the Qur'ān as a text generated by Muhammad; accordingly, they have attempted to read and understand the Qur'ān 
as an autobiography of Muhammad. Consequently, the Qur'ān text has been regarded as significant evidence about the life experience and psychology of Muhammad.

The division of the Qur'ān text with regard to revelation as a historical document intends to analyze the psychology of Muhammad, on the one hand, and to follow the progress of Islam, on the other hand. Nevertheless, the conventional mushaf arrangement does not actually serve the use of the Qur'ān as a historical reference because it includes neither a thematic nor chronological composition. For the utilization of the Qur'ān text as a historical document, the chapters and verse groups should be appropriately dated to establish a chronological order of revelation. ${ }^{70}$

Modern translations and exegetic works based on revelation order have primarily emerged from India and Egypt; this fact might be shown as proof for the influence and inspiration of the Orientalist tradition. Certainly, India and Egypt are Muslim regions that have been subjected to Western invasions. In his English translation of the Qur'ān first published in 1911 on the Indian subcontinent, Mìrzā Abū l-Faḍl (d. 1956) arranged the chapters pursuant to their order of revelation grounded on Nöldeke's arrangement, except for two chapters. Then again, Mawlānā Muhammad 'Alī (d. 1951), the leader of the Qādiyānīs in Lahore, on the Indian subcontinent, attempted to date chapters of the Qur'ān. First, in the prologue of his The Holy Qur'ān with English Translation and Commentary in 1917, there was a title entitled "Makkī and Madanī Chapters," in which he divided the Makkī chapters into three sub-periods and the Madanī chapters into four sub-periods.

Mawlānā Ya'qūb Hasan Sa'īd (d. 1940) was another personality to have published a similar translation-exegesis in India. Ya'qūb, who was imprisoned by the invading British and remained in jail between 1921 and 1923, studied the Qurān in the process and finally published two works, Kitāb al-hudā and Kashf al-hudā. These works, which included exegeses of verses on several themes, considered the revelation process.

70 For further information see Hadiye Ünsal, Erken Dönem Mekki Surelerin Tablili (Ankara: Ankara Okulu Yayınları, 2015), 98-119; Ömer Özsoy, Kur'an ve Taribsellik Yazıları (Ankara: Kitâbiyât Yayınları, 2004), 151-164. 
Many Egyptian Muslim scholars and researchers were also interested in the arrangement and exegesis of the Qur'ān pursuant to the chronology of revelation. For instance, Yūsuf Rashīd wrote an article in the 1950s about the necessity to arrange the Qurān pursuant to the chronology of revelation. Muhammad 'Abd Allāh Drāz (d. 1958) wrote another paper to criticize the aforementioned article, defending the necessity of obedience to the muṣhaf arrangement. ${ }^{71}$ Due to concerns emphasized by such and similar debates, Muhammad 'Izzat Darwaza opted to obtain a fatwā from Abū l-Yusr 'Ābidīn and al-Sheikh 'Abd al-Fattāh Abū Ghudda on the admissibility of exegetic writing pursuant to revelation order before beginning to write his exegesis entitled al-Tafsì al-ḥadith (Damascus 1961-1963), which was based on revelation order.

Apart from Darwaza, the 'Irāqī 'Abd al-Qādir Mullā Huwaysh (d. 1980) also realized an exegesis pursuant to the revelation order of the Qur'ān and published it under the title of Bayān al-ma'āni (Damascus 1962-1968) in six volumes. The fifteen-volume Ma'ärij altafakkur wa-daqā'iq al-tadabbur by the Syrian 'Abd al-Rahmān Ḥabannaka al-Maydānī (d. 2004) is a similar work. Al-Maydānī completed the exegesis of the Makkī chapters; nevertheless, he did not live long enough to write exegeses of the Madanī chapters. As'ad Ahmad 'Alī, born in Latakia, Syria, in 1937, also organized his Tafsìr al-Qur'ān al-murattab pursuant to the revelation order. ${ }^{72}$

Muhammad 'Ābid al-Jābirī was another modern Muslim academician who prepared an exegesis in line with the revelation order. In his three-volume commentary, entitled Fahm al-Qur'ān alhakìm, al-Jābirī followed the principle of explaining and commenting on the Qur'ān in line with opinions. His work comprised genuine and accurate findings and determinations; nevertheless, his mindblowing interpretations, such as "carrying on with a partner prior to sexual intercourse and stroking the skin of the woman gently in

71 See Muhammed Abdullah Draz, "Kur'ân-1 Kerîm'in Nüzûl Sirasına Göre Tertîb Edilmesi Teklifine Edebî Eleştiri” (translated into Turkish by Ahmed Nedim Serinsu), Kur'an Mesajı: Ilmi Araştırmalar Dergisi 2/19-20-21 (1999), 191-209.

72 For comprehensive information and assessment about these works, see Ṭāhā Muḥammad Fāris, Tafāsīr al-Qur'ān al-karìm ḥasaba tartīb al-nuzūl (Amman: Dār al-Fatḥ, 2011), 423-922. 
preparation for sexual intercourse" for the word daraba $^{73}$ in the section about the expression wa-dribübunna in $\mathrm{Q}$ 3:34, overshadowed the scientific worth of the work.

Similar studies were conducted in Turkey during the Republican Era. One of them was entitled Beyânu'l-Hak: Kur'an-ı Kerim'in Nüzul Sirasina Göre Tefsiri by the late M. Zeki Duman. Kur'an Yolu Iniş Sirasina Göre Anlam ve Tefsiri by Şâban Piriş and the elevenvolume Nüzul Sirasina Göre Tebyînu'l-Kur'an İste Kur'an (Istanbul 2008-2010) by Hakk1 Y1lmaz can be mentioned in the same category. In addition to the foregoing, many Turkish translations have been published in line with the revelation order.

One of the main factors underlying all of these works is the modern Muslim view that the Qur'ān is a self-sufficient source, as well as the formation of a serious awareness of the distance among Sunna, hadith, and tradition. In this regard, it is ironic that the problem of translation and exegesis according to revelation order, which necessarily requires the consideration of the Prophet and his attitudes, is popular especially in circles adopting a Qur’ān-based approach to Islam.

Most probably, the tendency among advocates of Qur'ān-based Islam toward exegesis pursuant to revelation order is about exploring a new field as a palliative approach to the problems of stringency and restrictedness due to countless repetitive lectures on the Qur'ān in the muṣhaf arrangement and lack of other satisfactory religious references. Otherwise, it is not explicable to omit any reference except for the Qur’ān as the source of religion and religious provisions, on the one hand, while planning to read it pursuant to its own history of revelation and attitudes, on the other.

\section{In Lieu of a Conclusion}

We can hardly discuss unanimously accepted revelation order or the arrangement of the Qur'ān. Moreover, it does not seem possible to establish such an arrangement in the light of the extant data. Above all, we lack sufficient information and knowledge about when every

73 See Muhammad 'Ābid al-Jābirī, Fahm al-Qur'ān al-ḥakīm: al-Tafsīr al-wāẹih hasaba tartīb al-nuzūl (Beirut: Markaz Dirāsāt al-Waḥda al-'Arabiyya, 2009), III, 222, 251-252. 
Qur'ān verse and chapter were transmitted. The reliability of the present data is contestable. Indeed, various revelation arrangements, provided by Companions and Followers, display significant differences; moreover, they are problematic in terms of documentation/certitude.

This being the case, we have observed an increasing tendency for understanding and interpreting the Qur'ān pursuant to the chronology of revelation. Regarding translations and exegeses, the preparation of or a lecture about a translation or exegesis pursuant to the revelation order does not provide the expected advantage or efficacy; furthermore, the intention for reading a translation undertaken in agreement with the revelation order remains unclear for us.

In case such a reading aims at obtaining a grasp of messages in the Qur'ān about humanity, the same can definitely be obtained through a muṣhaf-based arrangement. In case the objective is to learn better the experiences and struggles of Muhammad as a prophet, one must refer to exegeses, hadith sources, biographies, and history books for that purpose.

Lists of the nuzūl order are available in various sources; nevertheless, they have no greater function than providing restricted information and a rough idea about the time of the revelation of chapters. In fact, such lists might be helpful for an exegesis that seeks to understand and explain the Qur'ān within its peculiar context of descent and to interpret it for modern humanity. Arrangements in such a study might indeed be functional for determining the semantic restrictions and extension of the meaning of wordings in the Qur'ān and significant themes and key concepts, as well as for monitoring the progression of suspended judgments. In contrast, a translation or exegesis prepared pursuant to a self-proclaimed nuzūl order cannot provide even such secondary advantages.

\section{REFERENCES}

Abū Shāma al-Maqdisī, Abū 1-Qāsim Shihāb al-Dīn 'Abd al-Raḥmān, alMurshid al-wajīz ilā 'ulūm tata'allaqu bi-l-Kitāb al-'azìz (ed. Tayyar Altıkulaç; Ankara: Türkiye Diyanet Vakfı, 1986).

Abū Ḥayyān al-Andalusī, Muḥammad ibn Yūsuf, al-Baḥr al-muhīṭ, 11 vols., (Beirut: Dār al-Fikr, 1993). 
'Alī, Jawād, al-Mufașsal fì tārìkh al-'Arab qabla l-Islām, 10 vols., (Qom: Manshūrāt al-Sharīf al-Raḍī, 1380 HS).

al-Bāqillānī, Abū Bakr Muḥammad ibn al-Ṭayyib, al-Intị̣ār li-l-Qur’ān (ed. M. 'Isām al-Qựāt; Amman: Dār Ibn Ḥazm, 2001).

al-Bayhaqī, Abū Bakr Aḥmad ibn al-Husayn ibn 'Alī, Dalā'il al-nubuwwa wa-ma'rifat ahwāal șāhib al-sharī'a, 7 vols., (ed. 'Abd al-Mu'țī Amīn Qal'ajī; Beirut: Dār al-Kutub al-clmiyya, 1988).

Cerrahoğlu, İsmail, Tefsîr Usûlü, (Ankara: Türkiye Diyanet Vakf1, 1983).

Ḍāmin, Ḥātim Șāliḥ, Nuṣuṣs muḥaqqaqa fì uulūm al-Qur’ān al-karìm (Baghdad: Markaz Jamā'at Mājid li-1-Thaqāfa, 1991).

al-Dānī, Abū 'Amr 'Uthmān ibn Sa'̄id, al-Bayān fì 'add āya al-Qur'ān (ed. Ghānim Qaddūrī al-Ḥamad; Safat/Kuwait: Manshūrat Markaz alMakhțūtāât, 1994).

al-Dārimī, Abū Sa'̄ìd 'Uthmān ibn Sa'īd, Naqd 'Uthmān ibn Sa'īd 'alā lMarīsì al-Jahmì al-'añ̄ fì-mā iftarā 'alā llāh fì l-tawhìd (ed. Manșūr ibn 'Abd al-'Azīz al-Simārī; Riyadh: Aḍwā' al-Salaf, 1999).

al-Dārimī, Abū Sa'īd 'Uthmān ibn Sa'īd, al-Radd 'alā l-Jahmiyya (Kuwait: alDār al-Salafiyya, 1985).

Darwaza, Muhammad 'Izzat, al-Tafsīr al-ḥadìth, 10 vols., (Tunis: Dār alGharb al-Islāmī, 2008).

Demirci, Muhsin, Kur'ân Taribi (Istanbul: Ensar Neşriyat, 2005).

al-Dhahabī, Abū 'Abd Allāh Shams al-Dīn Muhammad ibn Ahmad ibn 'Uthmān, Siyar a lām al-nubalā', 25 vols., (eds. Bashshār 'Awwād Ma'rūf et al.; $2^{\text {nd }}$ edn., Beirut: Mu’assasat al-Risāla, 1981-1988).

al-Dhahabī, Muḥammad Husayn, al-Tafsìr wa-l-mufassirūn, 3 vols., (Beirut: Dār al-Arqam, n.d.).

al-Dihlawī, Shāh Walī Allāh, al-Fawz al-kabīr fì ușūl al-tafsīr (Damascus: Dār al-Ghawthānī li-l-Dirāsāt al-Qur’āniyya, 2008).

Draz, Muhammad 'Abd Allāh, "Kur'ân-1 Kerîm'in Nüzûl Sırasına Göre Tertîb Edilmesi Teklifine Edebî Eleștiri," (translated into Turkish by Ahmed Nedim Serinsu), Kur'an Mesaji: Ilmi Araştrmalar Dergisi 2/19-20-21 (1999), 191-209.

Fakhr al-Dīn al-Rāzī, Abū 'Abd Allāh Muḥammad, al-Tafsīr al-kabīr, 17 vols., (Beirut: Dār al-Kutub al-'Tlmiyya, 2004).

Fāris, Ṭāhā Muhammad, Tafāsīr al-Qur'ān al-karìm ḥasaba tartīb al-nuzūl (Amman: Dār al-Fatḥ, 2011).

al-Ḥalabī, Abū l-Faraj Nūr al-Dīn 'Alī ibn Burhān al-Dīn Ibrāhīm, Insān al'uyūn fì sìrat al-Amìn al-Ma'mūn (al-Sìra al-Halabiyya), 2 vols., (Cairo: al-Mațba'a al-Azhariyya, 1932). 
Ḥamīd Allāh, Muhammad [as Muhammad Hamidullah], İslâm Peygamberi, 2 vols., (ed. Salih Tuğ; Ankara: İmaj İç ve Dış Ticaret, 2003).

Ibn Abī Dāwūd, Abū Bakr 'Abd Allāh, Kitāb al-mașāḥif(ed. Arthur Jeffery; Leiden: E.J. Brill 1937).

Ibn Abī Shayba, Abū Bakr, Kitāb al-Muṣannaf fì l-aḥādìth wa l-āthārr, 7 vols., (ed. Mușțafā Kamāl Ḥūt; Beirut: Maktabat al-Zamān, 1999).

Ibn Abī Zamanīn, Abū 'Abd Allāh Muḥammad, Tafsīr al-Qur'ān al-'azīz, 2 vols., (Cairo: Dār al-Kutub al-'Ilmiyya, 2002).

Ibn 'Ādil, Abū Ḥafș 'Umar ibn 'Alī, al-Lubāb fì culūm al-Kitāb, 20 vols., (Beirut: Dār al-Kutub al-'Tlmiyya, 1998).

Ibn al-Athīr, Abū 1-Sacādāt Majd al-Dīn Mubārak ibn Muḥammad al-Jazarī, alNihāya fì gharīb al-hadìth wa-l-athar, 5 vols., (ed. 'Abd al-Hamīd Hindāwī; Sidon \& Beirut: al-Maktabat al-'Așriyya li-1-Tawzī' wa-lNashr, 2008).

Ibn al-Zubayr, Abū Jacfar Aḥmad ibn Ibrāhīm, al-Burhān fì tartīb suwar alQur'ān (ed. Muḥammad Sha'bānī; n.p.: Wizārat al-Awqāf wa-lShu'ūn al-Islāmiyya, 1990).

Ibn 'Aqīla, Jamāl al-Dīn Abū 'Abd Allāh Muḥammad ibn Aḥmad ibn Sa'īd, alZiyāda wa-l-iḥsān fì 'ulūm al-Qur'ān, 10 vols., (al-Shāriqa: Jāmi'at al-Shāriqa Markaz al-Buhūth wa-l-Dirāsāt, 2006).

Ibn 'Āshūr, Muḥammad al-Ṭāhir, Tafsīr al-taḥrīr wa-l-tanwìr, 15 vols., (Tunis: Dār Sahnūn, 1997).

Ibn Rāhawayh, Abū Ya'qūb Isḥāq ibn Ibrāhīm ibn Makhlad, Musnad Isḥāq ibn Rāhawavh, 5 vols. in 4 vols., (ed. 'Abd al-Ghafūr ibn 'Abd alḤaqq Ḥusayn Burr al-Balūshī; Medina: Maktabat al-Īmān, 1990-1991).

Ibn al-Ḍurays, Abū 'Abd Allāh Muḥammad, Faḍā'il al-Qur'ān wa-mā unzila min al-Qur'ān bi-Makka wa-mā unzila bi-l-Madina (ed. Ghazwa Badīr; Damascus: Dār al-Fikr, 1987).

Ibn Fāris, Abū l-Husayn Aḥmad, Mu'jam maqāyìs al-lugha, 6 vols., (ed. 'Abd al-Salām Muhammad Hārūn; Cairo: Muștafā al-Bābī al-Ḥalabī, 1979).

Ibn Ḥajar al-'Asqalānī, Abū l-Fạ̣l Shihāb al-Dīn Ahmad ibn 'Alī, Fatḥ al-bārī sharb Șahīh al-Bukhārī, 14 vols., (eds. 'Abd al-'Azīz ibn 'Abd Allāh Ibn Bāz, 'Alī ibn 'Abd al-'Azīz al-Shibk, and Muhammad Fu'ād 'Abd al-Bāqī; Riyadh: Dār al-Salām, 2000).

Ibn Hishām, Abū Muḥammad Jalāl al-Dīn 'Abd al-Malik, al-Sìra alnabawiyya, 2 vols., (eds. Mușțafā al-Saqqā et al.; Beirut: Dār al-Khayr, 2004).

Ibn al-Jawzī, Abū l-Faraj Jamāl al-Dīn, Funūn al-afnān fì 'uyūn 'ulūm alQurāān (ed. Șalāh ibn Fatḥi Halal; Beirut: Mu’assasat al-Kutub alThaqāfiyya, 2001). 
Ibn al-Jawzī, Abū l-Faraj Jamāl al-Dīn, Zād al-masìr fì 'ilm al-tafsìr, 9 vols., (Beirut: al-Maktab al-Islāmī, 1987).

Ibn Manẓūr, Abū l-Fạ̣l Muḥammad ibn Mukarram, Lisān al-'Arab, 9 vols., (Cairo: Dār al-Hadìth, 2003).

Ibn al-Nadīm, Abū 1-Faraj Muḥammad ibn Abī Ya'qūb, al-Fihrist (ed. Ibrāhīm Ramaḍān; Beirut: Dār al-Ma'rifa, 1997).

Ibn Rajab, Abū 1-Faraj al-Hanbalī, Lațā'if al-ma'ārif (ed. Yāsīn Muhammad Sawwās; Damascus \& Beirut: Dār Ibn Kathīr, 1999).

al-Iṣfahānī, Abū Nu`aym Aḥmad ibn 'Abd Allāh ibn Isḥāq, Dalā’il alnubuwwa, 2 vols. in 1 vol., (eds. Muhammad Rawwās Qal'ajī and 'Abd al-Barr 'Abbās; $2^{\text {nd }}$ edn., Beirut: Dār al-Nafā'is, 1986).

al-Jābirī, Muḥammad 'Ābid, Fahm al-Qur'ān al-karìm, 3 vols., (Beirut: Markaz Dirāsāt al-Waḥda al-'Arabiyya, 2009).

Jeffery, Arthur (ed.), Muqaddimatān fì 'ulūm al-Qur'ān: wa-bumā muqaddimat Kitāb al-mabānì wa-muqaddimat Ibn 'Atiyya (Cairo: Maktabat al-Khānjī, 1954).

Kister, Meir J., "et-Tehannüs: Kelime Anlamı Üzerine Bir Araştırma," (translated into Turkish by Ali Aksu), Tasavvuf: Ilmî ve Akademik Araştırma Dergisi 2/4 (2000), 215-230.

al-Māturīdī, Abū Manșūr Muḥammad ibn Muḥammad ibn Maḥmūd, Tảwīlāt Ahl al-sunna: Tafsīr al-Māturìdī, 10 vols., (ed. Majdī Bāsallūm; Beirut: Dār al-Kutub al-'Tlmiyya, 2005).

al-Nīsābūrī, Abū 1-Qāsim al-Hasan ibn Muḥammad ibn Habīb, Kitāb altanbīh 'alā faḍl 'ulūm al-Qur'ān (ed. Muhammad 'Abd al-Karīm Kāẓim al-Rāẹī), al-Mawrid: Majalla Turātbiyya Faṣliyya 17/4 (1988), 305-322.

Özsoy, Ömer, Kur'an ve Taribsellik Yazlları (Ankara: Kitâbiyât Yayınları, 2004).

al-Qāsim ibn Sallām, Abū 'Ubayd, Faḍ̂̄'il al-Qur'ān wa-ma'ālimub ${ }^{\bar{u}} w a-$ $\bar{a}$ dābuh ${ }^{\bar{u}}, 2$ vols., (ed. Ahmad ibn 'Abd al-Wāhịid al-Khayyātịi n.p.: alMamlaka al-Maghribiyya Wizārat al-Awqāf wa-l-Shu’ūn al-Islāmiyya, 1995).

al-Qurțubī, Abū 'Abd Allāh Muḥammad ibn Aḥmad, al-Jāmī' li-ạ̣kām alQur'ān, 21 vols. in 11 vols., (Beirut: Dār al-Kutub al-'Ilmiyya, 1988).

al-Rāghib al-Ișfahānī, Abū 1-Qāsim al-Husayn ibn Muhammad, al-Mufradāt fì gharīb al-Qur’ān (ed. Muhammad Khalaf Allāh; Cairo: Maktabat alAnjlū al-Mișriyya, 1970).

al-Shahrastānī, Abū l-Fatḥ Tāj al-Dīn Muhammad ibn 'Abd al-Karīm, Mafātīḥ al-asrār wa-mașābīh al-abrār, 2 vols., (ed. Muḥammad Ādharshab; Tehran: Mīrāth Maktūb, 2008). 
al-Shawkānī, Abū 'Abd Allāh Muhammad ibn 'Alī ibn Muhammad, Faṭ̣ alqadìr al-jāmi ' bayna fannay al-riwāya wa-l-dirāya min 'ilm altafsìr, 5 vols., (Beirut: 'Ālam al-Kutub, n.d).

al-Suyūṭī, Abū 1-Faḍl Jalāl al-Dīn 'Abd al-Raḥmān, al-Itqān fì 'ulūm alQur'ān, 2 vols., (ed. Mușțafā Dỉb al-Bughā; Beirut: Dār Ibn Kathīr, 2002).

Şen, Ziya, "Arza ve Mahiyeti," Dokuz Eylül Üniversitesi İlabiyat Fakültesi Dergisi 42 (2015), 43-64.

Şen, Ziya, Kur'an'in Metinleşme Süreci (Istanbul: Ensar Neşriyat, 2007).

al-Ṭabarī, Abū Ja'far Muḥammad ibn Jarīr, Tafsīr al-Ṭabarī al-musammā Jāmī‘ al-bayān fì ta’wīl al-Qur’ān, 12 vols., ( $3^{\text {rd }}$ edn., Beirut: Dār alKutub al-(Ilmiyya, 1999).

al-Ṭabarsī, Abū 'Alī al-Faḍl ibn al-Ḥasan, Majma' al-bayān fì tafsìr alQuràn, 10 vols., (Beirut: Dār al-Kutub al-'Tlmiyya, 1997).

Ṭabāțabā'î̀, Muhammad Ḥusayn, İslam'da Kur'an (translated into Turkish by Ahmed Erdinç; Istanbul: Bir Yayıncılık, 1988).

Tarakçı, Muhammet, "Tanah’ta Vahiy Anlayışı," Uludağ Üniversitesi Illahiyat Fakültesi Dergisi 11/1 (2002), 193-218.

Ünsal, Hadiye, Erken Dönem Mekki Surelerin Tahlili (Ankara: Ankara Okulu Yayınları, 2015).

al-Ya'qūbī, Abū l-'Abbās Aḥmad ibn Abī Ya'qūb ibn Jacfar ibn Wahb, Tārīkh $a l-Y a^{\prime} q \bar{u} b \bar{\imath}, 2$ vols., (ed. 'Abd al-Amīr 'Alī Mahnā; Beirut: Sharikat alA`lamī li-l-Maṭbū'āt, 2010).

al-Zarkashī, Abū 'Abd Allāh Badr al-Dīn, al-Burhān fì 'ulūm al-Qur'ān, 4 vols., (ed. Muhammad Abū l-Faḍl Ibrāhīm; Sidon \& Beirut: al-Maktaba al-'Așriyya, 1972). 